\title{
The Lagoon and Other Stories: Storytelling, Metafiction and the Framean Text
}

Janet Wilson

\section{(2) OpenEdition \\ Journals}

Electronic version

URL: https://journals.openedition.org/ces/8180

DOI: $10.4000 /$ ces.8180

ISSN: 2534-6695

Publisher

SEPC (Société d'études des pays du Commonwealth)

\section{Printed version}

Date of publication: 1 April 2011

Number of pages: 124-136

ISSN: 2270-0633

\section{Electronic reference}

Janet Wilson, "The Lagoon and Other Stories: Storytelling, Metafiction and the Framean Text",

Commonwealth Essays and Studies [Online], 33.2 | 2011, Online since 18 November 2021, connection on 06 January 2022. URL: http://journals.openedition.org/ces/8180 ; DOl: https://doi.org/10.4000/ces 8180

\section{cc) (†)}

Commonwealth Essays and Studies is licensed under a Licence Creative Commons Attribution - Pas d'Utilisation Commerciale - Pas de Modification 4.0 International. 


\section{The Lagoon and Other Stories: Storytelling, Metafiction and the Framean Text}

This article examines Frame's use of metafiction in three key stories of The Lagoon and

Other Stories, in order to show how the preoccupation with authorship, identity and storytelling controls her narrative structures. Referring to recent critical debate on the function of metafiction in her work, it argues that these early stories test out the limits of authorial presence through deconstructive strategies that problematise the voice, authority and authenticity of the narrator. The stories anticipate Frame's narrative practice as it develops in her novels; but the article concludes by noting that her concerns with absence, identity, and agency are reprised in the circumstances of the volume's publication and reception, a case in which art overtakes life.

\section{Frame and Metafiction}

Janet Frame's authorial self-consciousness about the constructedness of the text and the process of writing has been variously interpreted according to different theoretical, critical and philosophical approaches to her work. ${ }^{1}$ Most studies of metafiction's function in the Framean text have focused on the novels, which offer a more expanded metafictional dimension than the fabular or parable-like short stories. ${ }^{2}$ Yet the earliest short stories published in The Lagoon and Other Stories demonstrate Frame's methods in embryo, and their self-reflexiveness anticipates her experimentations in the novel, notably her engagement with narrative voice, authorial agency and identity. ${ }^{3}$ The stories examined in this article, "The Lagoon," "Jan Godfrey" and "My Last Story," demonstrate that, from the beginning, Frame's mode of interrogating her author figures, their textual being/being in the text, dominates the structures of her narratives.

Frame's metafictional texts, like others by twentieth-century writers, question their own status as fictions, and in engaging in a dialogue with generic conventions approach the function of criticism. As Mark Currie writes, such writers "personify the boundary between fiction and literary criticism" because acts of "interpretation constitute the world of experience which they (knowingly or unknowingly) represent" $(1,3)$. Jan Cronin has remarked of the theoretical density of Frame's texts, notably The Edge of the Alphabet, that in introducing intertexts from European discourses and working them into her own design, as well as re-presenting their own material, Frame formulates a method which is "akin to literary criticism" ("Theoretical Terrain" 62; "Through a Glass Darkly" 15). As she shows in relation to The Edge of the Alphabet, authorial interventions that signpost the author figure's engagement with the world of the text can be read in terms of an underlying pattern or argument, which the fiction exemplifies or expounds, therefore reworking its premises. This can be seen in the

1. For a survey see Cronin and Drichel, "Introduction" to Frameworks, xi-xvi.

2. But see Delrez, "The Legacy of Invention."

3. See Marta Dvorak's essay (146) and her reference to other essays in this volume which deal with Frame's issues of authorship, authority and authenticity. 
metafictional stories as well as in other self-reflexive novels like Living in the Maniototo and The Carpathians.

Cronin reads Frame as a philosophical writer, whose texts are hermetically sealed structures with their own "theoretical terrain." In The Adaptable Man, for example, this comes from the field of Christianised Platonism in a continuum of representation wherein mirrors are vehicles ("Through a Glass Darkly" 15, 17). Cronin attributes the "inherent provisionality" of the Framean text to slippages between its signification and methodology, the enactment or exposition (or hypothesis) of its premises; that is, to a discrepancy between what the texts say, "the themes and concerns, which potentially unify and even inspire Frame's novels, and the modus operandi [sic] of the individual texts, which subsume and subvert those same concerns" (Theoretical Terrain" 45). Metafiction is one critical strategy in the text's exposition or enactment of its thesis. In The Edge of the Alphabet, the ostensible concerns with identity, marginality and meaningful pattern are associated with the creator figure, Thora Pattern, who controls the novel's organisation. But this metafictional level is destabilised, as Thora's uncertainty and fear of false agency or self-delusion make it another version of the fiction it purports to comment upon, and she becomes a subject in her own fiction (or pattern) ("Theoretical Terrain" 52-53). For Marc Delrez, by contrast, who argues from a metaphysical, humanist approach, Frame's authorial commentaries belong to a "fiction of retrieval" (Utopia 45), and gesture towards either a "repository of eclipsed existence" (68) or towards excavating "the fossils of a forgotten past" ("Conquest of Surfaces" 137). This is in keeping with Delrez's interpretation of Frame's work in terms of a linguistic utopianism (Utopia 65) developed, he claims, in response to a sense of "eroded reality, both ontological and epistemological." Metafiction, therefore, as authorial comment on the work and a representation of its concerns makes explicit the amputations and occlusions inherent in the realistic representational mode ("Conquest of Surfaces" 140-41). To this extent it is part of a process of self authentification, underwriting (rather than undermining, as Cronin implies) the narrator's control over her fiction ("Theoretical Terrain" 52; Utopia 54). Both approaches, despite their differences (see Delrez "Conquest of Surfaces," 140), are informed by Frame's metaphysics, the search for "what is beyond the real, the invisible beyond the real" (Frame "Interview," 64), that is, for "a linguistic and ontological beyond" (Delrez Utopia, 124).

In this article I will draw on this recent criticism to argue that, in the context of a mutuality "between absence and presence, seeing or non-seeing" (Delrez "Conquest of Surfaces," 151), Frame establishes her authorial signature by decomposing the narrative voice and point of view, gesturing towards eradicated segments of reality. The process undermines the authorial presence, yet elements are covertly recuperated and affirmed in ways that can point to disruption in the exposition of a thesis. Narrative spaces, the fissures and silences that appear in the textual landscape, can be read both as constitutive of gaps between the present moment of writing and the disrupted past of reality, and as evidence of inconsistencies between the thesis of the stories and the apparent verification or enactment of its premises. I will also introduce a rehabilitated biographical approach in order to locate "Jan Godfrey" and "My Last Story" in relation to the circumstances in which the stories were written, and to 
suggest that their preoccupations are premonitory of the role that The Lagoon and Other Stories would play in Frame's life.

The opening story, "The Lagoon," "Jan Godfrey" (16 th out of 24 in the volume), and the concluding "My Last Story" collectively represent Frame's arguments about writing and authorship, life and art. They have also been read biographically as responses to absence, betrayal and contradiction, prompted by experiences of fear, disorientation and loss. Such readings foreground Frame's subject matter, ${ }^{4}$ but fail to account for her oblique modes of representation, which often subvert, critique or undermine these concerns. Each has a first-person narrator, each displays indeterminacy about narration and telling. For example, the story's existence ("The Lagoon"), the story's coming into existence and the narrator's agency and identity ("Jan Godfrey"), the narrator's attitude to storytelling and the story's non-existence ("My Last Story") all come under scrutiny. All three interrogate the function and status of the art of storytelling: "The Lagoon" approaches the question of the relation of story to "truth" and its exclusions in ways that recall Coetzee's retelling of Defoe's Robinson Crusoe in Foe (Hutcheon 107); "Jan Godfrey" tests out the role of authorship against the instability and deconstruction of identity; "My Last Story", reflecting a crisis of legitimisation, is preoccupied with textuality and the ontology of authorship.

\section{Fact and Fiction}

In "The Lagoon" the tensions between fiction and fact/truth first emerge through the narrator's desire for a special story, and the revelation to her of one which is a family secret. The narrator's self-consciousness about stories and storytelling is filtered through her comments about family history and observations of social changes during her visits to Picton, first as a child, then later as an adult. ${ }^{5}$ These are framed by a thirdperson narrator (later revealed as the grandmother who told her stories when the narrator was a child), who introduces in condensed form the imagery of the lagoon itself, a liminal space, and a dense symbol of the transformative possibilities of time and place. A repository for a buried, alternative history, the lagoon is constructed by the tidal ebb and flow that transforms it from a watery repository to a sandspit at low tide. As Cindy Gabrielle points out, it is a supreme example of waterscapes in all Frame's works, symbolising - as hinted at by its murky depths and muddy surfaces buried treasure, concealed secrets, occluded histories, forestalled stories, in short, "all that can be lost and subsequently retrieved, albeit only through memory" ("Poetics of Dissolution" 213).

The tidal fluctuations of the lagoon, its symbolic indeterminacy, can be read as a subjective correlative to the fluid and transformative storytelling process, as John Thieme suggests in his essay in this volume (85). The oscillations between narrative

4. Although the biographical approach has led to underreadings of Frame's work, the personal tragedy and trauma of her early years provide a crucial context for the stories; see Evans. Henke argues, with reference to the Autobiography, that Frame's psychiatric case history evidences abnormal bereavement and effects of post-traumatic stress disorder at this time (92). Editors' note: see the annex offering an explanation of Lagoon's writing backdrop by Pamela Gordon, Janet Frame's literary executor.

5. There is no date given for the composition of the "The Lagoon," but it may have been written after Frame's visit with her sister June, in the summer of 1946, upon her return from Seacliff to her mother's relatives in Picton, where "they heard new versions of the Godfrey family history" (King 77). 
voices, from the grandmother's in the opening sections, to the narrator's and then the aunt's, provide an image of moving in and out of consciousness, like the flux of the lagoon, and they undercut the temporal linearity associated with the family genealogy. The narrator's fascination with stories when a child also implies a valuation of storytelling: her desire for the "real," "proper" story of the lagoon (The Lagoon 8), by contrast to the grandmother's tales of herself when young, is fulfilled when she is told, upon returning to Picton as an adult, about a murder that suggests a fatal flaw in the family heritage: her great-grandmother, "the Maori princess with her big brown eyes, and her lace dress" (10), had drowned her husband by pushing him into the lagoon.

Storytelling is a form of intimate communication between the women in the family, and orally transmitted stories constitute a thread of recognition among the four generations. But Frame's critical matrix in this story is that writing (by contrast to oral storytelling) is a potentially damaging act of exposure, of making public. She implies a distinction between orally transmitted tales and written discourses such as legal writing, journalism, and literary fictions, by which stories might also be represented. The family's concealment of the secret implies shame, a degree of collusion with the deed, as well as a wish to preserve the great-grandmother's memory; this is now threatened by the narrator's knowledge. The aunt who introduces her to this glimpse of "truth" and the lagoon as a site of excavation, insists that it is merely "an interesting story," so undercutting the import of its facticity. In claiming a preference for "Dostoevsky to Truth" (11), she punningly invokes the scandal tabloid Truth, in which domestic crime, public disorder and wrong-doing were sensationalised in New Zealand at the time. The aunt acclaims art's superiority in representing affairs of the heart, in being able to overturn public perceptions of crimes like murder and recode them so as to preserve the private myth, and forestall crude moralistic judgements. But the narrator's retelling also exposes this as a fabrication.

Frame continues to destabilise the border between fact and fiction. The secret's concealment within the family is implied by the aunt's gesture of drawing aside the curtain as if lifting a veil, and then dropping it back. This defining moment corresponds to the narrator's transition from passive participant (audience to family stories) to that of commentator, scribe and family historian who will disseminate the family secret by committing it to paper. The cinematic gesture the narrator invokes the aunt "reminded me of the women in films who turn to the window in an emotional moment" - suggests that this added level of illusion might allow her to conceal an ethical impulse (which Simone Drichel ascribes to Frame), concerning her dubious act of putting into print, and so making public, a carefully harboured family secret ("Signposts" 185, 204). At this point, with the aunt's enigmatic quotation "The reason that one talks farthest from the heart is the fear that it may be hurt" (11) - the narrative begins to anonymise itself. Metafiction blends into fiction as the narrator asks whose voice is speaking from among her female forebears, and herself becomes invisible, as if in response to her own doubts and fears. Any conflict that the narrator might experience over her telling and betrayal of the family secret by writing the story down, rather than preserving silence for reasons of family loyalty, is masked as she vanishes among the older generations in a moment of textual erasure which recalls the traditions of oral storytelling. 
The truth status of the "real" story, therefore, remains ambiguous: it is close to myth - swallowed up once more into the family heritage and occluded from public consciousness - yet may never have been anything more than a fiction, a fabrication by the aunt and/or the narrator. But in the "false artifice" (as W.H. New puts it in his essay, 36) of the conclusion, the narrator further undermines her authority, as the grandmother's voice of the opening is repeated (see John Thieme's essay in this collection, 84-85), albeit with sinister implications. The words of "we" children who play happy families at low tide on the sand, followed by ellipsis - "you be father I'll be mother and we'll live here and catch crabs and tiddlers for ever..." (11) - imply either that suppressed histories when unexamined are capable of being repeated, or that the illusion of truth alone is perpetuated through hidden stories, which transmute into fairy tale upon successive retellings.

In "The Lagoon" writing and absence is finally privileged over speech and presence, for as frequently happens in Frame's fictions the thesis develops from the loss of a human being - here the ghostly husband - through a revelation that simultaneously converts the narrator's semi-autobiographical storytelling into the sharper focus of authorship. The moment when the narrator slips back into the depths of the past that had withheld the story from her as a child, neither reinforces nor undermines the narrative voice: instead it signifies an unresolved point of ethical or existential doubt about her narratological project. Or to put it another way, the story is affective, because the conclusion (and the grandmother's voice) now subsumes the voice that sought out the story and brought it into written existence. In "Jan Godfrey" and "My Last Story," by contrast, storytelling becomes a site of struggle, between different versions of the narrating self in the former, and competing representational modes in the latter. In these stories about the process of writing, authorial commentary functions as a mirror in relation to the fiction to which it refers. The "story" of "Jan Godfrey" consists of the narrator's questioning of her identity and collapsing of the boundaries between self and other, whereas in "My Last Story" denial becomes a covert form of assertion, as the narrator more explicitly undercuts her presence and hence her agency, fracturing the relations between text, author and subject matter.

\section{Authorship and Identity}

"Jan Godfrey" is based on the thesis that identity is constructed as a label or empty signifier, interchangeable with other labels and so able to be applied and discarded, seemingly at will. This theory is reinforced through reference to other sites of exchange, such as mutually exchangeable children and reduplicated cake papers, and it is enacted in the narrator's substitution of her name for someone else's. At the metafictional level is the author's quest to construct a story, articulated as problematic given her fragile identity and her case of writer's block, while the "fiction" consists of the narrator's struggle to tell the story involving her transformation into another person named Alison Hendry. Contributing to the blurring of fictional and metafictional layers is the confusion over the story's title, as Simone Oettli comments in her essay in this volume (99). "Jan Godfrey" has biographical resonance, as Godfrey was the maiden name of Frame's mother, and it was Frame's nom de plume 
when this story was first published in Landfall in 1947 (King 14, 85), although originally it was titled "Alison Hendry."

The story begins with a familiar metafictional trope - the author's comments on her inability to write a story - which yields to an identity crisis due to the narrator's subject matter: "the girl who sleeps in the room with me" (92). The narrative structure simulates competing stories, and the procedure exemplifies the authorial methodology that Cronin has identified in The Edge of the Alphabet, where a context of exploration (i.e. the story of Alison Hendry) literally subsumes the subject of the exploration (Jan Godfrey), becoming itself the substance of exploration ("Theoretical Terrain" 49). The colliding forces and rupturing divisions between the two voices, self and other, emerge out of the narrative process as Alison Hendry's story blurs into and absorbs that of Jan Godfrey; the story concludes with the narrator's declaration that she is now Alison Hendry.

The anxiety about composition with which the story opens, therefore, masks a deeper anxiety about erasure and loss of selfhood through division, splitting of identity and labelling, a process which has occurred in the past, it is implied. The suspension of time and the feeling that time has stopped ("perhaps I will be here for years and years and there will be no story" [91]), underline an existential state of nonbeing that is close to death. The story, Frame's biographer tells us, is partially set in a boarding house in Caversham where Frame was living in 1946 after her return from six weeks in Seacliff mental hospital, to which she had been committed on 3 November 1945 (Frame Autobiography, 200; King 73, 85). ${ }^{7}$ The narrator's deathlike trance is reinforced by the memory of "that other room" (91) (probably the room later recalled as the "linen room" [95] $)^{8}$ and her comparison to Juliet in Romeo and Juliet, entombed in a vault surrounded by artificial roses under a belljar. Parallel to the narrator's evacuation of selfhood is the suggestion that signs may have no meaning at all, that writing may be no more than disconnected signs, lacking signifieds. In typing words "that are not a story," the narrator introduces the image of childish writing as meaningless marks, a form of desecration, a stance that anticipates the narrator of her second novel, Faces in the Water. "A little girl made the scribbles with an H.B. pencil I lent her, round and round with her fat dirty hands, and afterwards the landlady said My best wall-paper, O my best wall-paper" (91). ${ }^{9}$ The loss of signification points to Derrida's decentred state when the sign reduces the signifier to itself, because it is separated from its signified, and lacking a centre, it is susceptible to the play of a number of sign substitutes (280-281). This deconstructive philosophy underpins the text's premise that people, lacking an original, can be substituted for each other by an exchange of names. The narrator's self-representation as decentred and deathlike, prone to uncanny doubling and dissolution, includes regression to an earlier state of being, and allusions to childhood and being away from home. It underlines the

6. The original title, "Alison Hendry," was changed to "Jan Godfrey" for publication in The Lagoon and Other Stories by Denis Glover; see King 84, 534 (footnote 51) who says the new title "made no sense in the context of the story."

7. The story came into John Money's hands on 13 September 1946. See King 84, 534.

8. This is similar to the linen room or cupboard in the mental hospital, Cliffhaven, described in Faces in the $W$ ater, as often a sanctuary for the narrator $(34,37)$.

9. In Faces in the Water, Frame's narrator speaks of scribbling on the wall with a pencil, during a period of solitary confinement (206-207). 
disconnectedness and dislocation that mark the fragmentation of self in the conclusion.

The story's tensions, therefore, are not only between writing and being/subjectivity, in which the self undergoes a symbolic death, a familiar theme of romantic poetry since Keats, but also in the splitting and division of the self, requiring it to be relabelled. Like the narrator who dissolves into her forebears in "The Lagoon," the narrator of "Jan Godfrey" undergoes in the writing process a selfdissolution into an ambiguous "other" - equivalent to a different person. As external proof of identity is impossible in this radically depleted universe (see Frame Autobiography, 193-194, cited in King 76), suggestive of life in the mental hospital, the narrator can only believe who she is according to her name: that is, words are labels to be accepted at face value (despite the arbitrariness of their assignations), but do not point to any substantial reality. As Allen Curnow says in his poem, "A Dead Lamb," of a found object washed up on the beach, "You say it is a Japanese fisherman's float./It is a Japanese fisherman's float" (Selected Poems 154). Frame's narrator's announcement of her transformation into Alison Hendry "demonstrates" this state of affairs.

Frame's procedure consists of three so-called digressions in which the narrator, Jan Godfrey, comments that she is wandering from her story (about Alison Hendry), but in fact draws attention to her own story in relation to the role of fiction in her life. A resistant reading suggests that this is a necessary deception to illustrate her reductio ad absurdum proposition, that words only signify, as signs without signifieds, in a process of constant deferral whereby your name "becomes" someone else's. In the first digression stories are evidently valued, as they are in "The Lagoon," for their opportunity for intimacy, notably as "payment for listening" to the teller. But Jan Godfrey's subjectivity - "the keyhole of my mind" - is invoked only to be radically decentred. The story here can be compared to other kinds of trauma fiction, which Cathy Caruth defines as "the plea by another who is asking to be seen and heard" (9). ${ }^{10}$ The repetition of "hell, me, me, me" (92) - in a layout in which the words follow each other on separate lines - suggests, as elsewhere in the story (the names of children, the cake papers mentioned in the penultimate line), an unassimilated experience, or the non-reception of experience that causes the collapse of its understanding (Caruth 4-10). In the second sequence the narrator asserts, but cannot prove, the interchangeability of identity between herself and Alison Hendry ("I cannot prove she is not me" [93]), claiming that names as labels create only superficial differences between people, who in fact are alike: the names - "Alison Hendry, Margaret Burt, Nancy Smith" - provide evidence, while being listed under the superordinate term "children" (93, 94).

This linguistic view of reality recalls Derrida's theories of signification, that signifiers when detached from their signifieds can be infinitely deferred and reconnected to others; that is, there is no centre but only a complex interrelationship of free play and supplement (Derrida 289). In the story's penultimate line, evacuation of being is suggested by the repetition of the word "cake papers" in the phrase "my

10. See Simone Oettli's suggestion in her essay in this volume (99) that this is a reference to John Money, to whom Frame gave the stories. 
mother is on the Institute, buying little frilly cake-papers, cake-papers, cake-papers" (97). As a public figure on the Woman's Institute, who has her name in the paper (by contrast to Mrs Hendry, who "presided"), the narrator's mother may have loosened ties with her daughter, contributing to the latter's disintegration of identity. The proximity of the mothers to each other parallels the proximity of the daughters, as the narrator conceives these overlapping identities, while the cake papers, as containers that lack cakes, are an analogue for words as signifiers without referents. Like the children - Alison Hendry, Margaret Burt, Nancy Smith - they represent sameness and duplication. The repetition of the word "cake-papers" echoes the earlier repetition of "me," and the same collapse of selfhood; it catalyses the transformation of the last line, the performative utterance: "My name is Alison Hendry."

The third digression, heralding the "arrival" of Alison Hendry, draws on the past as "other" to the time of writing, defining the narrator's move from the school at which she taught, to the Public Hospital in Dunedin, and then to a fortress-like mental hospital. A truncated citation of hospital rules culminates in "It is understood that on no account must..." (95). ${ }^{11}$ The ellipsis, suggestive of the breach in the official order that will occur, precedes the narrator's ominous act in the linen room, of trying on "a canvas jacket just to see" (95), and hence acquiring a new identity, so increasing the risk of being labelled in error. ${ }^{12}$ The metafictional comment which follows, "I have wandered again" (95), denotes a narrative jump, representative of an erasure of experience that is like "a gash" in reality, due to the severance of the self from the world; ${ }^{13}$ that is, the narrator becomes personless, dehumanised, through acquiring an unwanted social identity from which eventually she would have to dissociate. ${ }^{14}$ This comes as close as the story will allow to Frame's own traumatic experience at this time after being labelled as schizophrenic in Dunedin Public Hospital, stigmatised as a nonself in need of resubjectivisation (King 74, 78, 82). ${ }^{15}$ The narrator's restatement of her inability to "prove" whether it is Alison or herself now includes ontological, existential doubt, for doubting her own existence extends to "the rest of the world that is named and labelled and parcelled" (95). It also suggestively implies that the more impersonal Alison Hendry identity might be required in order to "supplement" the now abject, stigmatised Jan Godfrey. ${ }^{16}$

That Alison Hendry is another part of Jan Godfrey, replacing her as an alter ego or a surrogate, as occurs with Frame's narrators in later fictions like Scented Gardens for the Blind, Daughter Buffalo and The Carpathians, is generally agreed (Rhodes 127; Evans 38; Gabrielle "A Heart to Speak of," n.p.). In the final paragraph, the language fragments

11. In Faces in the Water, the narrator also comments on the old bathing list of fourteen rules, "issued at the beginning of the century," pasted on the bathroom wall (41).

12. See King 83, citing Frame, Autobiography (201), where Frame claims that she initially imitated symptoms of schizophrenia in order to gain attention. The diagnosis was overturned by psychiatrists at the Maudsley Hospital in London.

13. See Delrez in "Conquest of Surfaces" (142), citing Frame's The Adaptable Man (24).

14. In writing about Frame's autobiography, Simone Oettli points to a similar disappearance of the self at the moment Frame is labelled as insane (Surfaces of Strangeness 43).

15. Suzette A. Henke, in writing of the autobiography, comments: "The abjected [schizophrenic] outsider [...] has been resubjectivized through incarceration and materialized in the body of a 'stranger' to the earlier normative self' (94).

16. Although the transference from contrasting initial syllables [God-] to [Hen-] in names whose final syllables are near homophones [frey] and [dry] suggests a witty undercutting of this substitution. 
and syntax collapses, symbolising the chaotic cross-cutting transference of identity and the blurring of characters. The two voices and stories merge and overlap in ways suggestive of the Freudian processes of the unconscious, with condensation, displacement, and a disregard for sequence. Alison is dark, "too tall," "mouse-like, dressed in grey," knits in secret, does not "read the books that you read," and has come to the city to be a tailoress $(95,96)$. Mirrored statements about the weather and unattributed phrases about being from the country, and leaving home for the first time, underline their similarities. The emphasis on speech in the paradoxical "I speak all the time though there are not many words to my speaking," reenacts in a different verbal form the collapse of the self, described earlier as "hell, me, me, me," due to timidity, fearfulness and verbal inhibition. Allusions to people's silence "because they are frightened" and then to her own fear and the undermining of being with "I am neither separate nor complete nor important" (96) suggest the narrator's absorption into the environment she is describing.

As the voices become indistinguishable, allusions to home and the countryside introduce a crucial new intertext, catapulting the narrator's "arrival" onto the local literary landscape. The story's tissue of European literary references, recalled from the narrator's schooling (Romeo and Juliet, Sir Joshua Reynolds, Robert Browning, Giotto), now yields to a familiar text which gives voice to the world of the farm; the cacophonous sounds of magpies - "quardle oodle ardle wardle doodle" - the chorus of Denis Glover's iconic, best known poem, "The Magpies" (1941), that Frame read at this time in Allen Curnow's anthology, A Book of New Zealand Verse 1923-45, and about which she wrote in her autobiography as "perfectly recording their cries on a misty summer morning” (Autobiography 192-93; qtd. by King 80). The division of Frame's narrator and dissolution into another character/self corresponds to a simultaneous splitting away from the influences of European literature and culture her principle intertextual allusions in all the stories in The Lagoon - and the emergence of her voice alongside that of current New Zealand writing.

\section{A Poetics of Erasure}

More than the other stories in The Lagoon, "My Last Story" anticipates the position of deconstructionists like Derrida who, in despair of any other language with which to speak, adopt the practice of writing under erasure by using parentheses and quotation marks (Burke 121). The metafictional level dominates at the expense of the fictional, and content that would pass as fiction is metaphorically bracketed off. Unlike the tentative narrator of "The Lagoon," who mysteriously disappears when she has heard the story she craved, and of "Jan Godfrey," for whom writing is a form of internal division, the narrator of "My Last Story" has "arrived," and the "story" consists of her apparent farewell to her art. More overtly here than in the other stories, the ostensible themes and preoccupations at the metafictional level are subverted by the text's modus operandi.

Frame sets out to challenge the boundaries of realist fiction by claiming that she will renounce mimesis, but like other contemporary metafictional writers she cannot distance herself completely from realism (Waugh 18). As in the other stories, her conclusion destabilises the narrative voice, problematising the idea of closure and 
containment; but rather than disappear into the fictional stratum, as occurs in "The Lagoon" and "Jan Godfrey," the narrator repositions herself as author through her familiar strategy of reversal and indirection in order to assert her central premise: the precedence of the values of art over life.

In the metafictional manifesto that constitutes "My Last Story," the narrator's dismissal of realist, romantic conventions demarcates the limits of conventional mimetic representation. This anticipates Frame's moves beyond verisimilitude and her decomposure of reality in later work, as Marta Dvorak notes in her essay in this volume, citing various thinkers (137-138): her critique of "investments in reality" and the "incongruous adherence to naturalism" that Cronin notes ("Contexts of Exploration" 17), and the kind of "fraught realism" that Delrez discerns in the novels and attributes to "a hiatus [...] planted in the oppressive code of naturalism" ("Conquest of Surfaces" 141, 152). Frame adopts the rhetorical trope of the inexpressibility topos, so-called because of its source from the time of Homer in the "emphasis upon inability to cope with the subject"; in relation to personal eulogy, with which it was traditionally associated, the author invokes failure should the task be attempted (Curtius 159). The technique here is similar: Frame's narrator disavows her current practices while simultaneously drawing attention to what is allegedly being denied. The metadiscourse about writing, the avowed dislike of "putting he said she said he did she did" (121), in fact highlights her practice elsewhere in the volume, such as her use of reporting clauses for satirical purposes, as in the conclusion of "My Cousins who could eat cooked turnips," where the children imitate the affected speech of the adults: "and we said really is that so just fancy" (39). Elsewhere the denial smuggles back in a dimension of realism and some of the "discarded" subject matter anticipates Frame's later work. "I'm not going to write about my family and the house where I live when I'm in Oamaru, the queerest little house I've ever seen" (122) notably anticipates her first novel Owls do Cry about the Withers family, set in the fictional town of Waimaru, and beyond that the autobiography.

The narrator's rhetorical stance in commenting on her art, when considered in relation to the other stories in the volume, suggests that a radical severance by way of ending is needed in order to begin again. Yet the exclusions are less exhaustive than this as Frame negotiates her problematic relationship to realism. "Expressiveness," a signifier of bourgeois ideology according to Roland Barthes (Mythologies), as well as a style of writing, appears to be her target, reinforcing her use of the inexpressibility topos and the disclaimer, "Well I am not going to do any more expressing" (123). If this is a reference to the lyrical romanticism visible in many stories in The Lagoon, then her reiterated "I'm not going to write about..." appears to exclude the very source material that she needs to draw on in order to continue writing. The rejected cliché, "my sister has a heart of gold" as "that's how they express things like that" (122-3), for example, can be juxtaposed against the realistic style of "The Secret," where the child's anxiety about her sister's life-threatening heart condition makes her "put my hand over her body to feel if her heart was still going" (17-18). The concluding selfcritique - "I think I must be frozen inside with no heart to speak of" (123) - suggests that self-denial substitutes for any articulation of an alternative style. This recalls the deliberate substitution of self for another in "Jan Godfrey." 
As in the conclusion of "Jan Godfrey," a rhetorically-staged utterance marks the narrator's apparent resolution to embark on the last story, but now performativity is also aborted: "I'm going to put three dots with my type-writer, impressively, and then I'm going to begin..." (123). This is followed by the "real" moment of finality, the concluding sentence (of both story and volume), consisting of further authorial selfsubversion, elaborating a disjunction between the real world and the world of the text: "I think I have got the wrong way of looking at Life" (123). ${ }^{17}$ The framing of the ellipsis in this way suggests a cancellation, a deletion of the last story's content which, as Delrez points out, is similar to the deletion of an entire chapter in Living in the Maniototo ("Conquest of Surfaces" 141). ${ }^{18}$ Frame, in this conclusion, implies binary oppositions - between realism and anti-realism, bourgeois and avant-garde discourses. But in restaging the story's tension between rhetoric/style and content as another version of the traditional conflict between life/morality and art/artifice, this final refutation (which appears to be a further undercutting of her narrative status as author) of any claim to moral probity in relation to life can be read back through the distorting mirror that her metafiction offers in relation to the fictional level, as an implied assertion of the converse argument (recalling the aunt's comment in "The Lagoon" about the need to talk "farthest from the heart"), in this case that art is effective when it is neither purely mimetic nor moral, but conscious of its artifice.

\section{Frame as Author}

That The Lagoon and Other Stories was published at all is due to the efforts of John Money (whose pseudonym in Frame's work is John Forrest), Janet Frame's lecturer in psychology at the University of Otago in 1945, who gave her counselling for a year and who, in his own words, "rescued" many of the stories (Money 21; King 84). ${ }^{19}$ Furthermore, the history of its publication intricately reprises the volume's preoccupations and contents. Money took the stories north to the Caxton Press in Christchurch. The publisher and editor was none other than Denis Glover, whose poem "The Magpies" is quoted from in "Jan Godfrey," so providing a local literary context (King 87-88) for the confusing emergence of Alison Hendry out of Jan Godfrey. It is due to Glover that the stories have their current order beginning with "The Lagoon," with its broad social and cultural contexts, and concluding with "My Last Story," with its ambiguous articulation of her determination to continue evolving her distinctive aesthetic and practice, despite the hiatus in Frame's writing that the sense of closure in this story anticipates (as Simone Oettli points out in her article in this volume, 104), it would be ten years before she would begin her next work of fiction, Owls Do Cry). That The Lagoon, first published in 1951, was awarded the Hubert Church Memorial award for prose in 1954 for the best first book, and so saved Frame from the leucotomy that was planned for her, is a legend of New Zealand literary

17. As the order of the stories in The Lagoon and Other Stories was not Frame's but Denis Glover's, the appearance of finality is partly editorial; yet the sense of an ending in "My Last Story" is also prescient. Frame would write no more fiction for another decade.

18. By contrast to Renata Cassertano's view that the hiatus represents an attempt to speak (349), I suggest that the breach in the text represents closure and denial, an example of a "gash" in the world.

19. For a list of dates of when the stories were handed to Money, see King 534, footnote 50; "My Last Story" came into his hands on 5 July 1946. 
history (King 112). Just as remarkable is the way that the themes of "Jan Godfrey" can be read as metonymic of this volte face in her affairs. It would seem that the claims of the text - that words can be used to signify what their speaker wishes to state about her identity, and as labels can point to new identities - anticipated the recognition of Frame as a published, prize-winning author by the superintendent of Seacliff Hospital, Geoffrey Blake-Palmer (King 112), thus accomplishing a crucial reversal that eventually enabled her to free herself from the straitjacket of the medical diagnosis which imprisoned her for eight years

Janet WILSON, University of Northampton

\section{Works Cited}

BARTHes, Roland. Mythologies. Trans. A. Lavers. London: Cape, 1957.

BuRKE, Sean. The Death \& Return of the Author. Criticism and Subjectivity in Barthes, Foucault and Derrida. Edinburgh: Edinburgh University Press, 1992.

CARuth, Cathy. Unclaimed Experience: Trauma, Narrative and History. Baltimore \& London: Johns Hopkins University Press, 1996.

Casertano, Renata. "Falling Away from the Centre: Centrifugal and Centripetal Dynamic in Janet Frame's Short Fiction." Telling Stories: Postcolonial Short Fiction in English. Ed. Jacqueline Bardolph. Amsterdam \& New York: Rodopi, 2001. 349-356.

Cronin, Jan. "Contexts of Exploration: Janet Frame's The Rainbirds." Journal of Commonwealth Literature 40.1 (2005): 5-19.

- . "The Theoretical Terrain of the Text: Reading Frame through The Edge of the Alphabet." Journal of New Zealand Studies 2.3 (2003-04): 45-63.

—. “Through a Glass Darkly: Reading the Enigmatic Frame.” In Cronin and Drichel, 3-23.

Cronin, Jan, and Simone DriChel, eds. Frameworks: Contemporary Criticism on Janet Frame. Amsterdam \& New York: Rodopi, 2009.

—. "Introduction." In Cronin and Drichel, ix-xxvii.

Curnow, Allen. A Book of New Zealand Verse 1923-1945. Christchurch: Caxton Press, 1945.

—. Selected Poems. Harmondsworth: Penguin, 1982.

CuRrIE, Mark, Metafiction. London \& New York: Longman, 1995.

CuRTIUS, E.R. European Literature and the Latin Middle Ages. Trans. William R. Trask. Harper Torchbooks. New York \& Evanston: Harper \& Row, 1953.

DeLrez, Marc. "'Conquest of Surfaces': Aesthetic and Political Violence in the Works of Janet Frame." In Cronin and Drichel, 135-153.

- "The Legacy of Invention: Determinism and Metafiction in Jane Frame's Mona Minim and the Smell of the Sun." Journal of Postcolonial Writing 45.1 (March 2009): 27-36.

-. Manifold Utopia. The Novels of Janet Frame. Amsterdam \& New York: Rodopi, 2002.

DerridA, Jacques. "Sign, Structure and Play." Writing and Difference. Trans. Alan Bass. London: Routledge, 1978.

DRICHEL, Simone. "'Signposts to a world that is not even mentioned': Janet Frame's Ethical Transcendence." In Cronin and Drichel, 181-212.

Evans, Patrick. "'Farthest from the Heart': The Autobiographical Parables of Janet Frame." Modern Fiction Studies 27.1 (1981): 31-40.

Frame, Janet. The Adaptable Man. London: W. H. Allen / Christchurch: Pegasus Press, 1965.

—. Faces in the Water. 1961. London: The Woman's Press, 1980.

-. Interview with Elizabeth Alley. "An Honest Record: An Interview with Janet Frame." Landfall 178, 45.2 (June 1991): 154-168.

—. Janet Frame: The Complete Autobiography. London: The Woman's Press, 1990.

-. The Lagoon and Other Stories. $2^{\text {nd }}$ ed. Christchurch: Caxton Press, 1961.

Gabrielle, Cindy. "The Poetics of Dissolution: The Representation of Maori Culture in Janet Frame's Fiction." Journal of Postcolonial Writing 46.2 (May 2010): 209-220.

- . "A Heart to Speak of: Negative Capability in Janet Frame's 'Jan Godfrey'." Unpublished paper.

Henke, Suzette, A. Shattered Subjects: Trauma and Testimony in Women's Life-Writing. Basingstoke: Macmillan, 1998.

Hutcheon, Linda. A Poetics of Postmodernism: History, Theory, Fiction. New York \& London: Routledge, 1988.

KING, Michael. Wrestling with the Angel: A Life of Janet Frame. Auckland: Viking, 2000. 
Money, John. "On Being John Wilford and John Forrest." The Inward Sun. Celebrating the Life and Work of Janet Frame. Ed Elizabeth Alley. Wellington: Daphne Brasell Associates, 1994. 20-24.

Oettli van Delden, Simone. Surfaces of Strangeness: Janet Frame and the Rhetoric of Madness. Wellington: Victoria University Press, 2003.

RHODES, H. Winston. "Janet Frame: A Way of Seeing in The Lagoon and Other Stories." Critical Essays on the New Zealand Short Story. Ed. Cherry Hankin. Auckland: Heinemann, 1982. 112-131.

Waugh, Patricia. Metafiction: The Theory and Practice of Self-Conscious Fiction. London \& New York: Routledge, 1984. 